\title{
Střední Evropa a vznik Státu Izrael
}

Dne 20. dubna 2018 uspořádala Fakulta právnická Západočeské univerzity v Plzni mezinárodní konferenci s názvem „Střední Evropa a vznik Státu Izrael“, jejíž záštitu převzal jeho excelence Daniel Meron, velvyslanec Státu Izrael. Konference se zúčastnilo přes padesát aktivních a pasivních účastníků i významných tematicky angažovaných hostů z České republiky, Polska a Izraele. Vedle akademických pracovníků a studentů doktorského i magisterského studijního programu zde vystoupili také významní zahraniční hosté a zástupci organizací, které jsou spojeny s řešenou problematikou. Konference byla uspořádána jako představení dosavadních výsledků výzkumu problematiky právně-historických souvislostí československé pomoci při vzniku Státu Izrael, který je na FPR realizován pod vedením proděkana, JUDr. Viléma Knolla, Ph.D., širším týmem s vysokou účastí studentů. Realizace výzkumu je podporována i českým výborem Keren Kayemeth LeIsrael. Cílem konference bylo prezentovat jednotlivá dílčí témata výzkumu nejen v rámci řešitelské instituce, ale i veřejnosti, která byla na konferenci zastoupena. Řečníci ve svých příspěvcích, které zazněly v angličtině, češtině a polštině, představili zejména právní aspekty tématu se souvisejícími přesahy do dalších vědních disciplín. Jednotlivé konferenční bloky byly organizovány zejména na základě užších tematických preferencí, které prezentované téma nabízí.

Konferenci uvedl JUDr. Vilém Knoll, Ph.D., který představil dosavadní stav výzkumu a jeho další směřování. První blok konference zahájil svým vystoupením jeho excelence Daniel Meron, velvyslanec Státu Izrael, který ve svém prŕíspěvku shrnul význam spolupráce mezi Československem a Státem Izrael pro izraelskou stranu a vyzdvihl výrazné osobnosti, které s touto myšlenkou sympatizovali, zejména Tomáše G. Masaryka a Jana Masaryka, jejichž jméno zůstává dodnes spjato se Státem Izrael i v podobě náměstí a ulic, které nesou jejich jméno. Dalším, kdo se v tomto bloku ujal slova, byl JUDr. Michal Pacovský, prezident českého výboru Keren Kayemeth LeIsrael, s příspěvkem Keren Kayemeth LeIsrael a vznik Státu Izrael. V úvodu shrnul podstatu pojmu sionismus a jeho proměny v čase, a dále se pak věnoval roli, kterou sehrála organizace Keren Kayemeth LeIsrael při vzniku Státu Izrael, a její proměněné roli v současnosti. Poté vystoupil JUDr. Tomáš Pezl (FPR ZČU), jehož příspěvek Legal Aspects of Establishment of Israel shrnul právní problematiku vzniku britského palestinského mandátu a následně Státu Izrael, a dále některé mezinárodně právní aspekty, se kterými se muselo v těchto momentech potýkat sionistické hnutí. Dr hab. Marian Małecki, prof. WSA z právnické fakulty Jagellonské univerzity v Krakově, svým př́spěvkem na téma Stosunki polsko-izraelskie w latach 1947-1967 představil problematiku polskou optikou, tedy vztah Polska k židovskému obyvatelstvu 
žijícímu na jeho území a jeho dobový postoj ke vzniku Státu Izrael. Další vystupující účastník Vojtěch Vrba (FPR ZČU) v příspěvku s názvem Contract No. 410001 představil svůj dosavadní výzkum v oblasti prvních dodávek československých zbraní pro židovskou komunitu v Palestině, přičemž se zaměřil na smluvní ošetření prvního zbraňového kontraktu mezi ČSR a židovskou reprezentací a jeho historické okolnosti. Posledním řečníkem v tomto konferenčním bloku byl Bc. Pavel Homolka (FPR ZČU), který ve svém př́ispěvku na téma „Gifts from Uncle Sam“ - Punished and Redeemed shrnul vyšetřování, trestní stíhání a soudní procesy, které se odehrály s osobami zásobujícími během války o nezávislost Izrael letadly a dalším vojenským materiálem ze Spojených států amerických, který byl nezbytný pro vedení války a jehož měl Izrael nedostatek. Tito lidé v rámci své činnosti porušovali zákony Spojených států amerických a někteří za to byli odsouzeni.

Druhý blok konference zahájil svým vystoupením JUDr. Vilém Knoll, Ph.D. (FPR ZČU), který př́spěvkem Machal - zahraniční dobrovolníci v trestněprávním kontextu představil problematiku zahraničních dobrovolníků získávaných pro ozbrojené síly vznikajícího židovského státu se zaměřením na proces jejich verbování a vycestování do mandátní Palestiny, respektive do Izraele. Věnoval se také nebezpečí trestního stíhání v jejich domovských státech, a to na prŕíkladu právní úpravy USA, Velké Británie a Československa. V tomto bloku dále vystoupili: Bc. Sára Allafová (FPR ZČU), která přednesla př́spěvek s názvem B-17 - American Dream, který představil historické a právní kontexty nákupu a transportu letounů B-17 ze Spojených států amerických do Československa. Letouny B-17 byly pořízeny Židy žijícími ve Spojených státech amerických za účelem jejich úpravy, která byla realizována v Československu, a využití jako bombardovacích letadel ve válce o nezávislost. Michael Urban a Vojtěch Vrba (FPR ZČU) v příspěvku Of the Defence of a State and of the Protection of the Republic shrnuli veřejnoprávní aspekty, které provázely první zbrojní kontrakty mezi ČSR a židovskou reprezentací. Mgr. Marcel Peter (FPR ZČU) se ve svém vystoupení na téma Plán na rozdělení Palestiny a jeho (ne)aplikace v praxi dle rezoluce valného shromáždění OSN č. 181 ze dne 29. 11. 1947 zabýval plánem na rozdělení Palestiny a jeho uváděním do praxe a dalším vývojem situace na předmětném území s přihlédnutím k mezinárodně-právním a politickým okolnostem při řešení otázek závaznosti zmíněné rezoluce, s dopadem především na území Jeruzaléma, chartu OSN, apod. Markéta Šulcová a Markéta Dostálová (FPR ZČU) ve svém př́íspěvku pod názvem Alija - návrat domů představily právní rámce vystěhování československých občanů do Izraele obecně a dále speciální možnost vystěhování prostřednictvím organizování brigády vojenských dobrovolníků, která byla zformována a vycvičena na území ČSR pro nasazení v Izraeli, přičemž příspěvek kladl důraz na právní předpisy, které se na tyto procesy vztahovaly. Mgr. Jakub Hablovič a Vojtěch Vrba (FPR ZČU) v príspěvku s názvem Právní existence československého dobrovolnického sboru pro Izrael představili právní aspekty vzniku, průběhu a zániku tohoto výcvikového kurzu dobrovolníků tzv. brigády Hagana v Československu v roce 1948. Důraz byl kladen zvláště na smluvní zajištění celé akce a interní normativní akty, které se jí týkaly, přičemž toto bylo konfrontováno s pravděpodobným faktickým stavem, osvědčovaným výpověd’mi pamětníků i dalšími dostupnými prameny.

V třetím bloku konference vystoupil Bc. Vladimír Haník (FPR ZČU), který přednesl př́ispěvek s názvem Právní následky ilegální formy pomoci vznikajícímu státu Izrael, jehož obsahem byly potencionální právní následky, které hrozily občanům ČSR v případě 
odhalení jejich podílu na ilegální pomoci (dodávky zbraní a munice) rodícímu se státu Izrael. Dále vystoupil Mgr. Marián Byszowiec (FPR ZČU), jehož př́ispěvek Proces s vedením Protistátního spikleneckého centra v čele s Rudolfem Slánským se věnoval trestnímu řízení, které bylo vedeno proti Rudolfu Slánskému, bývalému tajemníkovi ÚV KSČ, a dalším obviněným z řad čelních představitelů KSČ. Autor se zaměřil na trestní řízení zejména s ohledem na tehdejší platnou právní úpravu, přičemž v prŕíspěvku posuzoval aplikaci hmotného a procesního trestního práva a dodržování „,socialistické“ zákonnosti. Zaměřil se přitom na jednotlivá stádia procesu od př́pravného řízení až po hlavní líčení. Bc. Andrea Hodinová a Mgr. Marián Byszowiec (FPR ZČU) pak v př́íspěvku s názvem „Sionistické spiknutíc v Československu - projev antisemitismu a neprátelství vůči státu Izrael v procesu s Protistátním spikleneckým centrem popsali projevy antisemitismu, které se objevovaly $\mathrm{v}$ průběhu trestního řízení vedenému proti obviněným z řad údajného Protistátního spikleneckého centra, které se nacházely i v reakcích na proces ve veřejném prostoru. Sionismus, národně-politické hnutí, zde nabýval významu nepřátelské ideologie zaměřené vůči lidově-demokratickému zřízení Československa.

Závěrečného slova a ukončení konference se ujal JUDr. Vilém Knoll, Ph.D., který prrítomné informoval o budoucím směřování výzkumu, jehož závěrečným výstupem bude kolektivní publikace na zkoumané téma a bude obsahovat témata na konferenci představená a mnohá další. Konferenční program byl mezi jednotlivými bloky doplněn přestávkami na kávu, kde proběhla živá debata mezi přednášejícími a posluchači.

doi: 10.14712/2464689X.2018.58

Jakub Hablovič 